\title{
Some Thoughts on University Disciplinary Proceedings
}

\section{Ira Michael Heyman*}

$\mathrm{C}$

YoNSTItutional DOCTRINE is too often used to define what ought to 1 be. Because the federal courts have refused to find de facto segregation covered by the doctrine of the Brown case, school superintendents conclude not only that nothing need be done to reduce racial concentrations in the schools, but that nothing should be done. ${ }^{1}$ Or, in the salad days of urban renewal, the narrow scope of constitutionally defined "just compensation" was seen as the wise measure of damages for relocatees despite the evident inadequacy of this formula to compensate for the many harms imposed on those whose lives were disrupted for the benefit of society. ${ }^{2}$

Much of the debate at Berkeley concerning "students' rights" and institutional authority has similarly been couched in constitutional terms. Student attention is focussed too much on claims of legal riglits to free expression which they assert must be lionored on the campus as well as off. The Regents reply that their pohicies "do not contemplate that advocacy or content of speech shall be restricted beyond the purview of the First and Fourteenth Amendments to the Constitution"3 without apparent support for a commitment to the merits of an open society. The General Counsel opines that a particularly ambiguous proposed general standard of conduct is permissible, citing a number of decisions in which judges, at various times in the past and on various doctrinal grounds, have refused to interfere with dismissal of students. Nothing is said about the dangers of a vague, open-ended standard (in this case that students are "required to observe generally accepted standards of conduct");" nor is any alternative language proposed which might better identify

* B.A., 1951, Dartmouth College, LL.B., 1956, Yale University. Professor of Law, University of California, Berkeley.

1 See Hemanan, Pubitc Schoors: Citres in the North and West-1963: OAkIand (1963) (Staff Report to the U.S. Commission on Civil Rights) 37. Compare Bell v. School City, 213 F. Supp. 819 (N.D. Ind.), af'd, 324 F.2d 209 (7th Cir. 1963), cert. denied, 377 U.S. 924 (1964), with Blocker v. Board of Educ., 226 F. Supp. 208 (E.D.N.Y. 1964).

2 See Urban Redeveloparent: Problems and Practices 449 (Woodbury ed. 1953); Millspaugh, Problems and Opportunities of Renewal, 26 LAw \& CoNTEMP. ProB. 6, 21, 24-31 (1961). See also Riley v. District of Columbia Redevelopment Land Agency, 246 F.2d 641 (D.C. Cir. 1957).

${ }^{3}$ University Bulletin, University of Califormia, Jan. 4, 1965, p. 97.

4 Letter from Thomas J. Cunningham, Vice-President and General Counsel, to the Regents of the University of California, April 21, 1965. 
University interests sought to be protected, and concomitantly give greater warning of what is proscribed. ${ }^{5}$

In this paper I do not intend to develop a constitutional theory concerning the "rights" of students or educational institutions. Many have recently done this. ${ }^{\circ} \mathrm{My}$ purpose, rather, is to look at the problems which ought to be faced by a law maker (be he regent, president, chancellor, faculty inember, or student) in fashioning procedures for student discipline. $^{7}$

The basic difficulty in establishing procedures is the conflict between two different but coexisting conceptions of the relationship between a university and its students.

The more traditional view, capsulated imprecisely in the words in loco parentis, stresses the quasi-familial nature of the relationship. The persons charged with ultimate disciplinary responsibility, exercise their authority benignly. They do not conceive of themselves or wisl to be viewed as policemen. They want to support students and help them through therapy and understanding. Students are counselled and their cooperation is expected. Deterrence, of course, is important and thus stiff penalties for major transgressions, such as cheating, are imposed. But the thrust is toward helping the offender become rule-abiding, much as parents seek to channel the behavior of children. ${ }^{8}$

The less traditional conception focuses on the institutional or corporate character of the university with the student seen as one of the institution's constituents. Students are independent adults free to behave as they wish subject to rules proscribing only that conduct importantly. detrinental to the functioning of the university. Higher education is a

5 "We must not be misled into assuming that where there are no legal rights there is no obligation to observe restraints on institutional authority." Monypenny, Toward $A$ Standard for Student Academic Freedom, 28 Law \& Contemp. Prob. 625, 628 (1963); sec Newman, The Process of Prescribing "Due Process," 49 CALIr. L. REv. 215, 239 (1961).

${ }^{6}$ See, e.g., Johnson, The Constitutional Rights of College Students, 42 TExas L. REv. 344 (1964); Seavey, Dismissal of Students: "Due Process," 70 HARv. L. REv. 1406 (1957); Van Alstyne, Student Academic Freedom and the Rule-MIaking Powers of Public Universities: Some Constitutional Considerations, 2 Law IN TRanstrion Q. 1 (1965); Van Alstyne, Proccdural Due Process and State University Students, 10 U.C.L.A.L. Rev. 368 (1963); Comment, Private Government on the Campus-Judicial Review of University Expulsions, 72 YaLE L.J. 1362 (1963); Note, The College Student and Duc Process in Disciplinary Proceedings, 1962 U. IIL. L.F. 438.

7 Two statements of basic principles are particularly helpful: Committee S, American Ass'n of University Professors, Statement on the Academic Freedom of Students, 51 AAUP BuLc. 447-49 (1965) [hereinafter cited as AAUP Stalement]; AMIERICAN CIVII LIBERTIES Unton, Academac Freedoms and Civil Liberties of Students in Colleges and Untversities (rev. ed. 1965) [hereinafter cited as ACLU Statemrent]. Sec also Van Alstyne, Procedural Due Process and State University Students, 10 U.C.L.A.L. REv. 368 (1963). Professor Van Alstyne was a meniber of the committee which prepared the AAUP Statement.

8 The articles cited in note 6 supra discuss these issues in some depth. 
government service (in the case of state colleges and universities) or a contracted for service (in the case of private institutions) to which its consumers have "rights."

These two conceptions, grossly overgeneralized, tug in opposite directions in structuring disciplinary processes. The familial notion leads to nonspecific rules and informal procedures. Strict legalities are eschewed because they create a wrong tone. Facts are to be determined by admimistrator's inquiries, not by courtroom combat. The governmental conception, on the other hand, pulls in the direction of formal proceedings of an adversary character to determine the guilt of an independent actor and the appropriate sanction to impose. The impetus toward formal proceedings derives strength from the recognition that the student being disciplined is subject to penalties which range up to expulsion and the consequent loss of the chance to get a college degree.

The law maker should recognize the existence and values of both conceptions. Gradations of them are infused throughout the campus cominunity. Many students, even though they vigorously deplore a familial characterization in the abstract, want supportive and sympathetic treatment when they are involved in a concrete case. But informality necessarily threatens dispassionate fact-finding, rule-making, and sanction-imposing processes, especially in those few, but nevertheless important, cases in which students rebel against university policies.

Three determinations usually must be made in disciplinary proceedings: (1) Did the student commit the alleged act? (2) If so, is it a violation of university rules? (3) If so, what sanction should be imposed? The challenge is to devise a decision-making structure and a set of procedures which will make these determinations fairly while preserving an atmosphere of support where advisable.

I

\section{DECISION-MAKING STRUCTURE}

Some university entity inust process cases initially. The Dean of Students at Berkeley, as at many other institutions, serves this function. His office receives and investigates complaints, determines their seriousness, interviews alleged offenders, seeks cooperation, accommodation, and informal solution, and imposes minimal sanctions, for instance warnings, if appropriate. Minor transgressions can be handled privately at this

8 "In developing responsible student conduct, disciplinary proceedings play a role substantially secondary to counselling, guidance, admonition, and example. In the exceptional circumstances when these preferred means fail to resolve problems of student conduct, proper procedural safeguards should be observed to protect the student from the unfair imposition of serious penalties." AAUP Statement 449. 
point with the least embarrassment and harm to the student. Formal sanctions prove unnecessary to procure the student's cooperation in the future and the persuasiveness of the Dean is heightened by the noncriminal tone of the interviewing.

But cases where the facts are in doubt, or the student does not agree that his conduct violated expected norms, or which involve major transgressions punishable by serious sanctions such as expulsion, suspension, or recorded reprimand cannot easily be resolved so informally. At Berkeley these cases are referred to a faculty-student discipline committee which holds a hearing and makes a recommendation for its resolution to the Chancellor who almost without exception has followed its advise. ${ }^{10}$ The availability of a hearing group independent of the Dean's office is crucial for a number of reasons. First, it is capable of using more formal (and thus more protective) processes for fact-finding than is the Dean's office, which seeks to avoid an adversary cliaracter. Second, it permits the Dean's office to maintain its supportive character-the committee, not the Dean, judges the seriousness of the case and the appropriate sanction. Third, its independence from the administration permits it to give content to general regulatory norms which are more consonant with campus consensus than might be the more isolated interpretations of an administrative official. Finally, it can shield student transgressors from excessive sanctions in those few cases where administrative officials are pressured to take extramural factors into account "for the good of the university." $\rightarrow$

Approximately ninety per cent of the disciplinary cases at Berkeley involve cheating, stealing, and disorderly conduct. ${ }^{11}$ The bulk of the students involved are undergraduates. The faculty-student discipline committee, chaired normally by a law professor, varies its procedures depending upon the issues in the case. Usually a student admits the charge in all but insignificant detail and attempts to explain or justify. The hearing in that event consists mainly of listening to the student, questioning him, and reviewing his record. Occasionally the committee deals with a serious case where the student denies the allegations. In such cases the hearing is more extended, with the student afforded the opportunity to question those who witnessed his alleged acts.

The committee's proceedings tend to combine inquisitorial with adversary characteristics. The committeemen are not passive judges refereeing between prosecutor and defense counsel who operate within a prescribed set of rules. Rather, the committee receives a set of allegations

10 Lesser student judicial committees impose minor penalties directly in some instances.

11 Letter from Professor Ronan Degnan, Chairman of the Faculty-Student Discipline Committee, to the Acting Chancellor, June 18, 1965. 
and then does what it believes is necessary in eacl case to satisfy itself of what occurred and what, if any, penalty should be imposed given its perception of the offender.

For the great bulk of cases this process seems satisfactory: The facts are usually correctly determined, the propriety of the acts are judged with regard to the community's (and the offender's) expectations of whether the acts were permissible, and a suitable punishment is imposed given the background of the student. ${ }^{12}$

But a paternalistic character is not appropriate to some types of cases. A host of specified and unspecified violations occurred last year at Berkeley, for instance, when a number of students sought to force changes in rules respecting political activity. These were not "usual" cases. The students distrusted the University administration-including the faculty-student discipline committee. The explosive quality of a rebellion, the bitter feelings of many administrators toward what they saw as arrogant conduct, the outside pressures for retribution, and the adversary positions of the Free Speecl Movement (FSM) and the University, required an unusually independent tribunal applying quite formal procedures for finding facts and imposing sanctions. In response to this need, the $A d$ Hoc Committee on Student Discipline of the Academic Senate was created. It was specially selected by the faculty for a single proceeding involving eiglit students who had been summarily suspended. Its hearings were quite formal. The students and the University were represented by counsel. The University was asked to draw charges specifically alleging violative conduct and the rules allegedly broken. The University put on its case. Counsel cross-examined. A written transcript was kept. The Committee's recommendations were made in a formal opinion which eventually was acted upon by the Regents. ${ }^{13}$

The procedures of the $A d H o c$ Committee are for the unusual case. The expense (1300 dollars for the transcript alone) and the time (thirtyfive hours of hearings and deliberations by five faculty members) are important considerations. Of more importance, however, is that students ought not to be forced to go through as a matter of course what can be the terrifying experience of a criminal trial.

The accommodation which has been reached tentatively on the Berke-

\footnotetext{
12 The present chairman of the committee at Berkeley has stated that in the usual case "the procedures should not be so different from family approach to terrify, yet they must not be so similar that they console the student with the feeling that he can revert to being a child." Ibid.

13 Regential action in that case was extraordinary; normally chancellors act upon such recommendations with the President involved only in expulsions.
} 
ley campus is to offer a student the opportunity to request a formal hearing before a hearing officer instead of a hearing before the facultystudent discipline committee. ${ }^{14}$ The officer is chosen from a panel provided through the Academic Senate-the formal faculty organization. ${ }^{15}$ He renders advice directly to the Chancellor. Thus the choice of procedures is the student's. ${ }^{16}$

This choice of alternatives is a desirable way to accommodate disparate conceptions of family and government. It offers a formal judiciallike proceeding in those situations where legitimacy requires greater formalities-the appearance as well as the reality of complete independence between the administration and the judges. On the other hand, it maximizes the values of informality, understanding, and supportiveness in the bulk of usual cases where highly adversary proceedings tend to be destructive and will not be chosen.

\section{II}

\section{DECISION-MAKING PROCEDURES}

Different decision-making bodies call for different procedures. Apart froin notice requirements, $I$ intend in this section to explore mainly procedures applicable to cases brought before a hearing body which is independent of the administrative office (the Dean) handling disciphine problems in the first instance. I shall discuss procedural elements at two levels-a less formal one (as with the described faculty-student discipline committee) and a more formal one (as with a liearing officer or panel).

\section{A. Notice}

A student should be notified of the acts he allegedly committed which are the subject of the charge. He should also be notified of the nature of the alleged violation. The charges should be in writing. ${ }^{17}$ Written

14 Provisional Regulations Concerning Procedural Fairness in Student Discipline Cases § 3, Sept. 16, 1965 [hereinafter cited as Provisional Rules].

15 Under the Provisional Rules the Chancellor chooses a hearing officer from the panel in each individual case. Provisional Rules $\$ 3$. It might be preferable if the choice was otherwise made, for instance, by the autonatic assignment in turn from the list of hearing officers selected by the faculty committee.

16 The choice can only be made intelligently if the student understands the choices available. Adequate publication of the rules is the first step. In addition, the Dean in the mitial interview should explain the alternatives.

17 According to a survey made by Professor Van Alstyne in 1962-1963 of seventy-two state universities, fifty-three per cent did "not provide students with a written statement specifying the nature of the particular misconduct charged, and only seventeen per cent 
charges accomplish two things: The administrator formally establishes for himself that there is a basis for charges; the student gets adequate warning (and thus some time to prepare and seek advice) before an initial conference. ${ }^{18}$

\section{B. Public Hearing ,}

The committee's hearing should be public unless the student asks for a closed hearing. ${ }^{19}$ The presence of observers helps establish an atmosplere of impartiality, and thus legitimacy. Often, however, in the case of informal hearings, a student will want privacy, and this desire slould be respected. While a request for privacy will rarely be made in more formal proceedings, for here the student normally will want a full panoply of adversary characteristics, a rule giving the hearing entity discretion to hold open liearings in such instances does not seem arbitrary. If there is wide-spread campus interest, as with the FSM defendants this past year, the hearing officers ought to be able to conduct the proceedings in sucli a way as to assure the whole community of the integrity of the process. On the other hand, discretion to hold public hearings ought not to be exercised against the student's wishes in other cases (for instance, involving a disputed cleating matter) where the fairness of the whole process is not in question.

\section{Counsel}

A student should be given opportunity to be accompanied by a lawyer, teacher, parent, or friend at the conmittee's hearings. ${ }^{20}$ Nothing is lost

provided such a statement at least ten days before the determination of guilt or imposition of punishment." Moreover, sixteen per cent of the institutions did not even provide for hearings. Van Alstyne, Procedural Due Process and State University Students, 10 U.C.I.A.L. REv. 368, 369 (1963) [hereinafter cited as Van Alstyne Survey]. The AAUP Statement requires written charges. AAUP Statement 449. The ACLU Statement requires explicit notification which at the students' request should be put in writing. ACLU STATEMENT 12.

$18 \mathrm{It}$ is important that the student be informed at the initial conference that he may remain silent if he wishes. See note 25 infra and accompanying text.

19 The Provisional Rules at Berkeley, apparently, have been interpreted to provide for open hearings only in formal proceedings. For the reasons given in the text I believe the other course would be wiser. Neither the AAUP Statement nor the ACLU Statement treats this question.

20 According to the Van Alstyne Survey, 30\% of the institutions did not allow the student charged to be accompanied by an advisor of his choice. Van Alstyne Survey 369. The AAUP Statement provides that "the student appearing before the hearing committee should have the right to be assisted in his defense by an advisor of his choice." $A A U P$ Statement 449. The ACLU Statement would have the student "free to seek the counsel of a faculty member of his choice or other advisor." ACLU STATEMENT 12. Neither statement discusses the role of the advisor or says anything about lawyer participation. 
by giving the student the chance to confer with a counsellor during the proceedings if he wishes. His confidence is bolstered and the committee might be aided.

There are two variables to be considered in determining the proper role of counsel. First, whether counsel is a lawyer. Second, whether the hearing is informal or formal.

Students will be represented by lawyers only rarely if the informal hearing is chosen. Counsel, if any, will be a layman who will help the student by speaking with him, directing an occasional question to witnesses, and, perhaps, addressing the committee in support of the student. A lawyer will want to participate more fully. He may wish to crossexamine witnesses in detail, put his client on the stand, and make motions concerning the admissibility of evidence. That kind of participation may suggest to the university that its case slould also be presented by counsel, and what began as an informal proceeding will tend to become adversary, and similar to the formal proceeding. If informality is desired, the participation of lawyer-counsel slould be limited to advising the student, seeking to ask questions of witnesses through the committee (unless under the circumstances the committee determines that direct questioning would be helpful to it), and summarizing the case for the student. This restriction on the role of lawyer-counsel for the student is reasonable, furthermore, since the student may, by cloosing the more formal process, get the full participation of counsel.

The university should not be represented by counsel in an informal proceeding.

Formal proceedings are probably best conducted where both sides are represented by lawyers. Formal proceedings will be chosen either because the alleged offenders distrust the university (as in the FSM situation) or because the alleged offense may result in a serious sanction such as expulsion. In both instances, active participation by lawyers will safeguard the fact-finding process and will support the acceptability of the eventual judgment. Students should seek their own counsel; if the student is indigent, normally voluntary representation will be possible, at least on a large campus. This is especially true in cases involving political matters where organizations like the American Civil Liberties Union are available. In other cases, slould an indigent student's efforts be unsuccessful, the university should help him obtain representation. The problem is eased on campuses with law schools. If the case burden is not severe, law teachers working with law students (or in many instances, law students alone) can service the demand. 


\section{Presentation of Evidence}

There should be no ex parte consultations in either type of hearing. ${ }^{21}$ The fact finder should not rely in determining guilt on evidence unavailable to the student. ${ }^{22}$ This is a crucial rule in safeguarding the process from erroneous and untested bases for decision, and especially applicable in a university context where those judging routinely come in contact with acquaintances who know individuals who liave been charged. In addition, and to the same end, the student should be told who the witnesses against him are and he should have a chance to question sucli witnesses. He should also have the opportunity to present any evidence he wishes, to rebut the charge or minimize his culpability.

No model is completely appropriate as a guide to how the case should proceed. In the $A d$ Hoc Committee proceeding at Berkeley last year it was found workable to have the University establish a prima facie case by a reading of the allegations contained in the complaint buttressed by brief testimony of witnesses. The students' counsel then questioned these witnesses. This was followed by minimal further questioming by University counsel. The suspended students testified and counsel for both sides summarized. Throughout the proceeding the Committee inquired extensively. Formal rules of evidence were not apphed. Thus hearsay was admitted subject to counsels' admonitions concerning its probity.

There were very few arguments concerning procedure. Two chief factors were responsible. First, the Committee held an extensive pretrial conference at which consensus was reached on the basic ground rules. Second, the parties trusted the fairness of the procedures and believed in the impartiality of the Committee. Confidence in impartiality was constantly reinforced by scrupulous forbearance of any ex parte contact

21 This, in my view, is the most important principle to be applied. The AAUP Statement is most specific here: "In no case should the committee consider statements against him [the student] unless he has been advised of their content and of the name of those who made them, and unless he has been given an opportumity to rebut unfavorable inferences which might otherwise be drawn." AAUP Statement 449. And, in addition: "All matters upon which the decision may be based must be introduced into evidence at the proceeding before the hearing committee. The decision must be based solely upon such matter." Ibid.

According to the Van Alstyne Survey, 26\% of the universities surveyed did "not permit the student charged to question informants or witnesses whose statements might be considered by the hearing board in determining guilt . . ." Van Alstyne Survey 369.

22 I have himited myself to evidence relating to guilt and have not dealt with factors which might be taken into consideration in imposing penalties where guilt is found. Initially I believe that information germane to punishment also should be disclosed and "tested." But I have not had sufficient time to acquaint myself with special problems concerning confidentiality (for instance of medical records) which might be involved in the publication at a hearing of such information. 
with either side. This forbearance was evidenced in numerous small ways (for instance by duplicating for both counsel copies of letters received from faculty members asking for lenient treatment of the students).

The experience of the $A d B o c$ Committee indicates that procedures and "technicalities" pose no serious impediments if the parties trust the decision-making institution. Consensus is possible if there is a shared attitude that the process is fair.

\section{E. Self-Incrimination}

Should a student be required to speak against himself? The question does not arise often because students generally do not refuse to answer questions concerning their cases. But this is not always true. ${ }^{23}$

We deal with two kinds of questions asking incriminating answers in the context of university discipline: (1) where the suspected act is a crime (for example, theft of property); and (2) where the suspected act is not a crime, but nevertheless violates a university rule (for example, cheating on an examination). If students should be required to answer either or both types of questions, a separate rule punishing refusals to answer could be enacted, or guilt of the charged conduct could be inferred from the student's recalcitrance.

I oppose a separate rule which punishes a student for refusing to answer incriminating questions whether the alleged act is a crime or only a breach of university rules. ${ }^{24}$ No doubt a dean ought to be able to call a student in for a conference-there should be enforceable compulsory process. In the usual case, undoubtedly, a student will want to discuss his alleged misbehavior. ${ }^{25}$ But if he does not, I think he should be protected in his silence, at least against the threat of punishment solely for maintaining silence. A separate rule requiring disclosure, unless delicately administered, invites significant intrusions into the private lives of students.

First, it facilitates calling in a student on very hittle independent evidence of rule violation. If a student can be required to state whether or not he did $X$ or $Y$, the temptation will be to short circuit outside inves-

23 Counsel objected when the University sought to question the students charged before the Ad Hoc Committee in the October 1964 proceedings at Berkeley. In the spring 1965 hearings involving the "foul word" dispute at least one student who had been charged declined to testify at all.

24 The Berkeley Provisional Rules provide that "no one will be required to give selfincriminating evidence." Provisional Rules $\$ 2$ (a) (vi). Both the AAUP and ACLU statements are silent on this matter, although the AAUP Statement on a related problem provides that "the burden of proof should rest upon the officials bringing the charge." AAUP Statemient 449. 25 Adequate warning must be given at this point if the student is to be afforded the right to remain silent. 
tigation and require a disclosure at the very outset. This possibility can lead to a process in which students are often questioned about a wide variety of matters concerning their conduct or the conduct of their peers. This might produce either of two unwise collateral effects. Timid students might overcompensate in view of the threat of being called before a dean and seek to conform their behavior to a detailed notion of how they suppose the university wishes them to act. Rebelhous students, on the other hand, probably would confront such a system with "marginal" acts in order to evidence their independence and establish their freedom from detailed parental-hke supervision.

Second, in any particular situation there might be many reasons for a student wanting to remain silent. He might not want to implicate others. He might have an ahibi which involves associations or conduct which he wants to keep private.

In the "outside" world a person may refuse to incriminate himself. ${ }^{28}$ This privilege has been supported as a bulwark against the rack and the screw, or, less emotionally, as a prime stimulant for civilized crime detection processes within the context of an adversary system. ${ }^{27}$ Neither consideration is particularly relevant in a university setting. But two other arguments are. First, in Professor David W. Louisell's words: "It is essentially and inherently cruel to make a man an instrument of his

20 The privilege against self-incrimination in two situations is especially relevant: (1) the defendant in a criminal trial and (2) persons under suspicion in preliminary investigatory proceedings. The law is roughly as follows:

(1) A defendant in a criminal trial has the right not to testify at all. If he chooses to testify in his defense, however, he is generally open to all relevant inquiries about the charges against him. See Rogers v. United States, 340 U.S. 367 (1951), made applicable to the states in Malloy v. Hogan, 378 U.S. 1 (1964), and Murphy v. Waterfront Comm'n of N.Y. Harbor, 378 U.S. 52 (1964). Under recent cases the prosecutor may not comment adversely on the defendant's failure to testify. E.g., Griffin v. California, 380 U.S. 609 (1965). Moreover, the defendant normally is entitled to an instruction by the judge to the jury that the failure to testify shall not be taken against him. MCCORMnCK, EvIDENCE $\S 132$ (1954). Nevertheless, most observers believe that juries often infer guilt from the defendant's failure to testify. Id. at $\S 136$; Meltzer, Required Records, The McCarran Act, and the Privilege Against Self-Incrimination, 18 U. CHr. I. REv. 687, 689-93 (1951).

(2) The privilege does not prohibit the questioning of suspected persons in police interrogations. But other rules concerning counsel, fair warning, and coercion have limited the admissibility at trial of confessions and incriminating statements made during such preliminary investigations. See generally Comment, The Right to Counsel During Police Interrogation: The Aftermath of Escobedo, 53 CarIF. I. Rev. 337 (1965).

In grand jury proceedings, legislative investigations and other formal proceedings a witness, be he a "suspect" or not, is entitled to refuse to answer incriminating questions. Quinn v. United States, 349 U.S. 155 (1955) (legislative investigation); Emspak v. United States, 349 U.S. 190 (1955) (legislative investigation); Rogers v. United States, 340 U.S. 367 (1951) (grand jury).

27 McCoranck, Evidence $§ 136$ (1954). 
own condemnation."28 Second, in Professor Meltzer's: "[The privilege] is a reflection of the law's unwillingness to command the impossible, of its respect for the law of self-preservation. ... It is also perhaps a reflection of a humane attitude that saves even the guilty from a harsh choice among perjury, recalcitrance, or confession."20 These reasons, in addition to those already mentioned, oppose a rule requiring a student to answer "incriminating" questions. We should realize that serious noncriminal, university sanctions-expulsion or long term suspension-are considerably harsher than punishments often resulting from criminal proceedings.

These arguments may not persuade some. Others might hold that a university is the kind of institution whose members must be frank and open with one another; that a university cannot support a full blown adversary system of criminal justice both because of costs and tone; and thus inquiry, not prosecution, is the way to proceed. But any rule requiring disclosure should surely be limited to situations involving noncriminal violations of university rules. No student ought to be required to answer any question if the answer might lead to conviction of a crime else university disciplinary proceedings become criminal discovery processes for district attorneys. Further, care should be taken that students do not unwittingly make incriminating statements. For instance, a disciplinary committee ought not to ask whether a student stole someone's property, thus inviting an answer which may lead to a criminal prosecution over which the university has no power.

The second kind of sanction against remaining silent would be to infer commission of the alleged act from silence. This sanction becomes relevant in a fact-finding process before a disciplinary committee. This sanction is not as troublesome as a separate rule requiring disclosure because the inference probably will be drawn whether or not it should be. A rule barring such an inference probably will only influence what is said in the committee's written opinion, not what occurs in the committee members' minds in determining guilt or innocence. If the university, either through a dean in informal proceedings or through counsel in formal proceedings, makes a prima facie case of violation, ${ }^{30}$ the inference drawn from silence can only be corroborative.

\footnotetext{
28 Louisell, Criminal Discovery and Self-Incrimination: Roger Traynor Confronts the Dilemma, 53 CAITF. L. REV. 89, 95 (1965).

20 Meltzer, supra note 26 , at $692-93$.

30 This would be necessary to support written charges in the first instance. Moreover, the preclusion of a separate rule requiring incriminating disclosures should result in a process in which charges are never preferred initially unless there is independent evidence of guilt. See text accompanying note 25 supra.
} 
There are three choices available concerning the making of inferences. First, a rule could state that a disciplinary committee may draw no inferences from a student's failure to testify. As stated, this seems an inoperable piety and might unfairly induce unwise silence. Second, a rule could state that once a student testifies at all, he is open to any question relevant to the charges and his failure then to respond is separately punishable. This is the case in criminal trials in many jurisdictions where the defendant voluntarily testifies. ${ }^{31}$ But I object to this on grounds similar to those leading to my rejection of a separate rule generally requiring a student to answer "incriminating" questions. Third, a rule could permit a student to offer testimony but refuse to answer specific questions giving whatever explanation he wishes. ${ }^{32}$ Under this third approach, which I find preferable, the committee could draw any inference it wished in light of the student's explanation for his total or selected silence.

\section{F. Record}

There should be record keeping in both informal and formal hearmgs, although the nature of the records may differ.$^{33}$ The primary reasons for record keeping are to enable the committee members to recall what occurred in comphicated proceedings, to provide a basis for review by the final authority, and to preserve a history of the proceeding against which to evaluate the decision rendered. In formal proceedings a tape recorder is adequate, although a written transcript would be desirable, at least in those exceptional cases where subsequent detailed study of the record is a probability. The latter, however, is very expensive and there are practical difficulties in obtaining the services of an experienced court reporter who will be able to transcribe notes rapidly. In most informal proceedings, where guilt is admitted, there is no necessity for a verbatim record; a digest by the chairman should suffice. Where guilt is in question in such proceedings, however, a taped record preserved for at least six months would seem wise.

\section{G. Imposition of Sanctions}

I have assumed throughout this paper that final authority to impose serious sanctions will he with an important university official. At the

81 See note 26 supra.

32 This would be analogous to the Anglo-American practice prior to the mid-nineteenth century which "permitted" a defendant to make unsworn statements because he was deemed incompetent as a sworn witness.

83 The AAUP Statement provides: "In the absence of a transcript, there should be both a digest and a verbatim record, such as a tape recording, of the hearing." AAUP Statement 449. 
University of California this authority is lodged in Chancellors except Presidential approval is required for expulsions. ${ }^{34}$ In some other universities, apparently, the faculty, through appropriate committees, is the ultimate decision-maker. ${ }^{35}$

There are two likely alternative arrangements. One lodges decisionmaking authority in a faculty, faculty-student, or student committee, subject to an appeal by a "convicted" student to an administrative official who may reverse or reduce the penalty. Under the other, the fact-determining body advises an administrative official who alone may impose sanctions.

The choices are largely indistinguisliable if, as at Berkeley, the advising committee writes an appropriate opinion to accompany its recommendation whicl it provides to the student (and thus to the public if the student wishes) and the administrative official indicates that he will not impose a sanction greater than that recommended other than on the record before the fact-finding committee. The possible distinction, of course, lies in the administrative power to enlarge the penalty, but the probability of this occurring after the publication of the advising committee's opinion is slim. In such case, the administrative officer would undoubtedly give the student opportunity to argne the significance of the facts and the appropriateness of the penalty before acting. ${ }^{36} \mathrm{~A}$ student should be assured the opportunity to comment in writing on the committee's recommendation and opinion as a matter of course in any event, for the administrator can always lower the penalty if he believes this wise.

\section{CONCLUSTON}

Universities are not equipped to nraintain prosecuting officers and criminal courts. But this does not mean that serious punishments should be imposed without the safeguard of processes and procedures designed to assure that facts are determimed correctly and sanctions imposed reasonably. Somewhat facetiously last year a member of the University community indicated that if he were Chancellor at the Berkeley campus during the "foul word" dispute he would lrave ascertained rapidly what had

34 University of California, Policies Relating to Students and Student Organizations, Use of University Facilities, and Non-Discrimination \& II, pt. E(b) (3), July 1, 1965.

35 The AAUP Statement provides: "The decision of the hearing conmittee slould be final, subject to the student's right of appeal to the governing board of the institution." AAUP Statement 449. The ACLU Statement assumes that the college administration may reject the hearing board's decision either as to guilt or punishment, but provides for appeal to the governing body (for example, a Board of Trustees) in such cases. ACLU STATEMENT 13.

${ }^{30}$ The Berkeley Provisional Rules are silent on this matter although they assure that the involved student will be informed of the recommendation made to the Chancellor. 
happened and then would have expelled the offending students immediately. Unfortunately too many persons seriously respond in this way when a crisis is upon them. They depend on informal and often erroneous factgathering means. And they impose sanctions without the careful weighing of complex considerations that can only be done after dispassionate reflection. Careful mquiry and reflective consideration are necessary preconditions for legitimately imposing punishınents. This paper hopefully aids university law makers in the task of building disciplinary institutions to assure the existence of these preconditions. 